\title{
Cost comparison and optimization of gas electric hybrid heat pumps
}

\author{
Amirkhizi, Tara S.; Jensen, Ida Græsted
}

Published in:

Wiley Interdisciplinary Reviews: Energy and Environment

Link to article, DOI:

10.1002/wene.370

Publication date:

2020

Document Version

Peer reviewed version

Link back to DTU Orbit

Citation (APA):

Amirkhizi, T. S., \& Jensen, I. G. (2020). Cost comparison and optimization of gas electric hybrid heat pumps. Wiley Interdisciplinary Reviews: Energy and Environment, 9(3), [e370]. https://doi.org/10.1002/wene.370

\section{General rights}

Copyright and moral rights for the publications made accessible in the public portal are retained by the authors and/or other copyright owners and it is a condition of accessing publications that users recognise and abide by the legal requirements associated with these rights.

- Users may download and print one copy of any publication from the public portal for the purpose of private study or research.

- You may not further distribute the material or use it for any profit-making activity or commercial gain

- You may freely distribute the URL identifying the publication in the public portal

If you believe that this document breaches copyright please contact us providing details, and we will remove access to the work immediately and investigate your claim. 
THIS IS THE ACCEPTED VERSION OF THE FOLLOWING ARTICLE “AMIRKHIZI TS, JENSEN IG. COST COMPARISON AND OPTIMIZATION OF GAS ELECTRIC HYBRID HEATPUMPS.WIRES ENERGY ENVIRON. 2020;E370.HTTPS://DOI.ORG/10.1002/WENE.370". THIS ARTICLE MAY BE USED FOR NON-COMMERCIAL PURPOSES IN ACCORDANCE WITH THE WILEY SELFARCHIVING POLICY

Article Title:

Cost comparison and optimisation of Gas Electric Hybrid Heat Pumps Article Type:

COPINION

ADVANCED REVIEW
(C) PRIMER

(- FOCUS ARTICLE
C OVERVIEW

C SOFTWARE FOCUS

\section{Authors:}

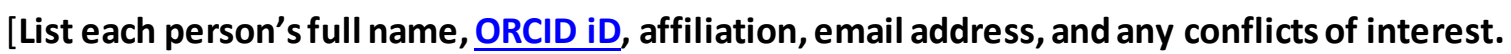
Copy rows as necessary for additional authors. Please use an asterisk $(*)$ to indicate the corresponding author.]

\section{First author}

[Tara Sabbagh Amirkhizi*, https://orcid.org/0000-0001-6873-5298, DTU Department of Management Engineering, tasaam@dtu.dk]

Second author

[Ida Græsted Jensen, https://orcid.org/0000-0001-7409-3439, DTU Department of Management Engineering, idje@dtu.dk]

\section{Abstract}

The residential heating sector can offer significant load-shifting possibilities to the energy system. Currently 400,000 households in Denmark are heated by natural gas boilers. The power consumption corresponding to these boilers can offer high value to the stabilisation of the wind intensive Danish energy system. Gas Electric Hybrid Heat Pumps (GEHHPs) are individual heat pumps consisting of an electric heat pump and a gas boiler. They provide a fully flexible operation of electricheat pumps by supplementing electricity with gas when necessary. In this paper, we construct a cost optimisation model of a GEHHP and compare the levelised cost of heat of this system with other individual heating systems. We investigate the changes in the operation schedule of the GEHHP, both from a socio- and a private-economic perspective, and analyse how certain economic and technological framework conditions influence their operation schedule. Our article shows that the end-consumer's optimal operation schedule uses the gas boiler component of the GEHHP $24 \%$ of the time. Additionally, 
comparing the Levelised cost of heat of the GEHHP with other heating alternatives proves that the GEHHP setup is the most cost efficient individual heating alternative.

\section{Graphical/Visual Abstract and Caption}

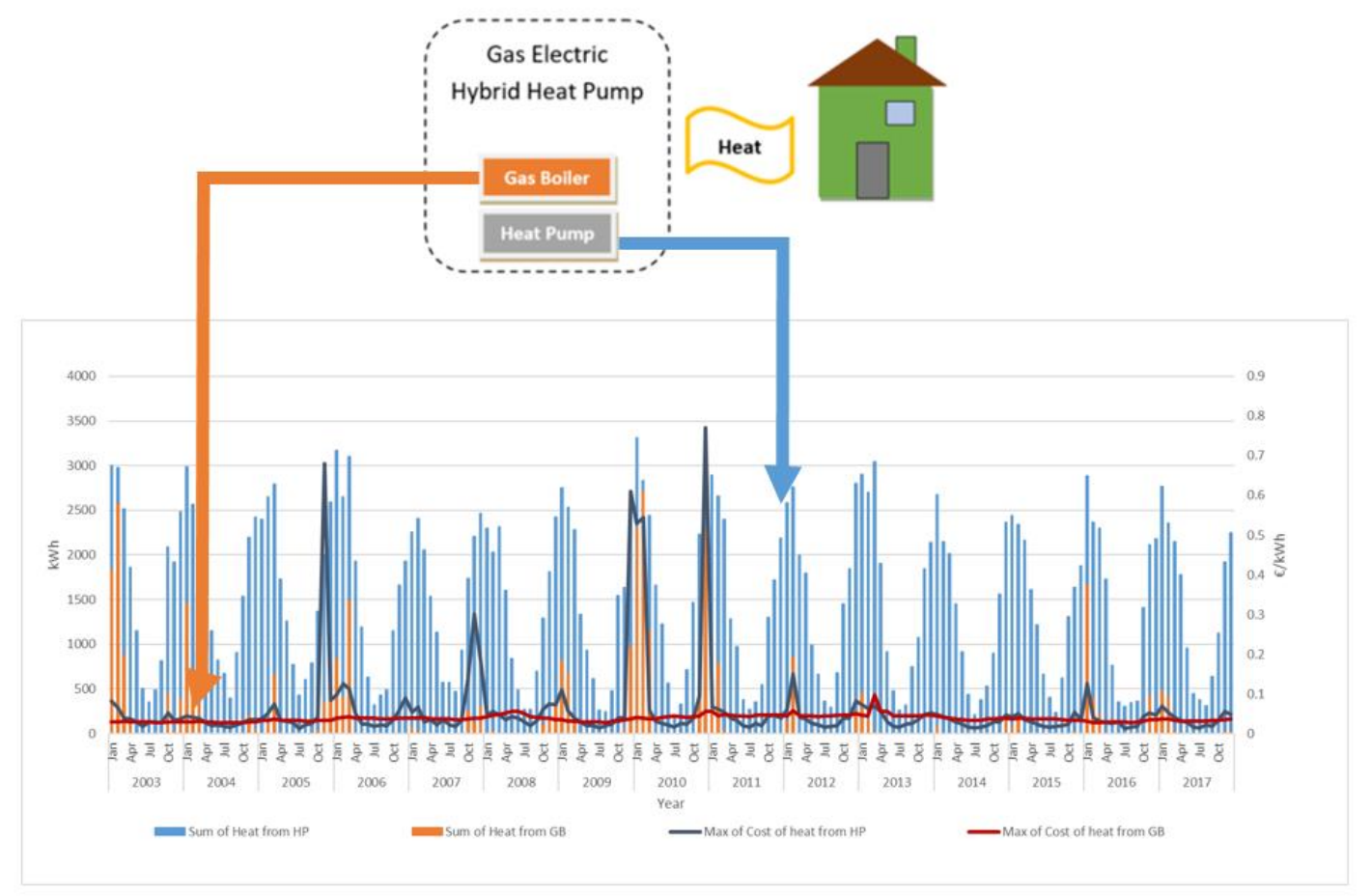

Caption: The optimal operation of Gas Electric Hybrid Heat Pumps (GEHHPs)

\section{INTRODUCTION}

The Danish state aims to be fully independent from fossilfuels by 2050 (Danish Energy Agency, 2015). A renewable based energy system consists of many volatile power resources such as wind and solar energy that present new challenges for the energy system (Brown, Zhou and Ahmadi, 2018). The emergence of flexible energy loads and producers is thus crucial to reach this objective by 2050 (Tuohy, Kaun and Entriken, 2014; Söder et al., 2018). The residential heating sector, generating around $80 \%$ of Europe's final residential energy use (Heinen, Burke and O'Malley, 2016), offers a large potential for providing flexible energy consumers to the power system (Hedegaard and Münster, 2013).

We refer to a system consisting of a natural gas boiler and an add-on electric air-to-water heat pump as a gas electric hybrid heat pump (GEHHP). GEHHPs have a flexible power consumption pattern. They can switch between a gas boiler and an electric heat pump at any time. It is common to optimise the overall cost- and heating- efficiency of the heating system using GEHHP s by utilising the electric heat pump when it is more cost-efficient than the gas boiler and the gas boiler during times when the heat pump is less efficient and more expensive (low temperatures and high electricity prices). Converting existing gas boilers to GEHHP systems reduces the gas consumption of households significantly. With such a decrease, households can realistically cover their gas demand from green gas (Energinet, 2018). 
As far as we know, there have not been any publications optimising the operation co sts of GEHHPs on a household level, considering taxes and grid tariffs. Our optimisation is based on market arbitrage, using both private, and socio economic costs and prices, while taking the hourly variable efficiency of the heat pump component into account. This enables an analysis that visualises the cost competition between the gas boiler and the heat pump, for fulfilling a Danish household's heating demand over the lifetime of the heating system.

Our study is twofold. First, we investigate the optimal operational schedule of the gas boiler and the heat pump components of the GEHHP, thenwe compare the optimal costs of the GEHHP system with other heating alternatives, namely, heat pump-only and gas boiler-only systems. We subject the GEHHP system to three scenarios: 1) The private-economic scenario, meaning the inclusion of taxes and nominal prices, 2) Time of Use (ToU) electricity grid tariffs, and 3) Replacing natural gas with biomethane as an input to the gas boiler component of the system. The focus of the first part will be the operation schedule, while the focus of the second part is the optimal costs of the system over its lifetime.

\section{LITERATURE REVIEW}

A number of studies show that the residential heating sector can contribute to the stabilisation of the energy system by increasing the power demand during certain hours, and offering load-shifting possibilities (Lund et al., 2015). According to Fischer and Madani (2017), heat pumps have the potential to ease the transition of the energy system to one with a higher share of renewable energy resources and prosumers, given they can be controlled appropriately. Especially when operated according to the electricitymarket, heat pumps can offer load shifting capacities to the energy system, while leading to cost savings up to $18 \%$ for the household owning the heat pump, compared to an operation scheme that does not consider electricity prices (Biegel et al., 2013). This argues for increasing the flexibility of electric heat pumps, by introducing an additional heating source, or extended heat storage to the heating system of individual households.

Additionally, there are high costs connected to the installation and grid integration of electric heat pumps on a large scale (Meibom et al., 2007; Guminski et al., 2018). Combining electric heat pumps with gas boilers can reduce these costs and enables the gas grid to offer flexibility to the power system (Schweitzer et al., 2014; Energinet.dk, 2018).

Hybrid heating systems are generally accepted by households, especially when they consist of a supplementary heating source added to a main heating source (Ruokamo, 2016). However, there are a number of challenges facing consumer load management. One of these challenges can be the consumer price, which is calculated based on an average power price and hence, does not incentivise the consumers to offer their load flexibility to the grid (Brown, Zhou and Ahmadi, 2018). Bergaentzlé et al. (2019) studied the effect of alternative tariff schemes, such as ToU electricity tariffs on the flexibility and cost optimisation of district heating plants and showed that ToU tariffs incentivise flexible power consumption in the district heating sector and reduce the overall heating costs.

The literature has evaluated the benefits of GEHHPs considering economic and strategic indicators in the past. Klein, Huchtemann, and Müller (2014) have developed a model of GEHHPs on a benchmark household in Germany and reached energy savings of $12-24 \%$ compared to conventional gas boilers. In their study, mid-range sized heat pumps have reached the best performance factors in the 
combined system. Bagarella, Lazzarin and Noro (2016) have evaluated hybrid heating systems in a dynamic model in a cold-humid, and mild-dry climate. They have concluded lower annual gas and electricity consumption for both climates using GEHHPs compared to a heat pump only system. Park et al. (2014) model a GEHHP that is only used for water heating purposes and investigate the effect of both water, and air temperature on the system performance. Their economic feasibility analysis of the system for an ave rage Korean apartment results in $4 \%$ annual cost savings compared to a gas-fired water heater. They conclude that the power price and the operation strategy of the system have a strong effect on its feasibility. Li, Zheng and Tian (2013) also highlight the importance of the operation strategy of hybrid heating systems, where the comparison between a hybrid heat pump system and a coal-fired boiler resulted in a $45.2 \%$ reduction in energy consumption and $13.5 \%$ reduction in operational costs. Di Perna et al. (2015) model a hybrid heat pump system in a single household optimising the size of the heat pump. Their study shows that the hybrid heat pump system results in higher efficiency values compared to a heat pump system with electrical integration. Hohne, Kusakana and Numbi (2018) developed a model of a hybrid heating system consisting of a solar water heating system and an electric water heater under a ToU tariff scheme. Their analysis shows that this heating concept enables load shifting without compromising the heat demand.

In Denmark, the "Danish Gas TechnologyCentre (DGC)" investigated GEHHPs in 2013 in a pilot project. The results of the project emphasised that GEHHPs increase the efficiency of a building's heating source (Frederiksen, 2014). A project facilitated by the Danish Transmission system operator (TSO) Energinet concluded that GEHHPs can decrease the pressure on the power grid during peak hours in a future, when the Danish heating sector is electrified, since they can reduce electricity consumption on days where the electricity demand is high (Energinet, 2018). Analyses in other countries, such as the freedom project in the United Kingdom, have shown that GEHHPs can utilise the increasing shares of renewable electricity and green gas in the energy system for a fully decarbonised heating sector (Freedom Project, 2018).

\section{THE MODEL OF A GEHHP AND THE FRAMEWORK CONDITIONS}

In order to compare the optimal costs of the different systems and scenarios, we use the Levelised Cost of Heat (LCOH) approach as used in (Sneum and Sandberg, 2018). Our base analysis consists of socio-economic prices and costs and represents the costs and optimal operation of the GEHHP from the society's point of view. For the socio-economic analysis, we follow the guidel ines from the Danish energy agency (Danish Energy Agency, 2017). All prices are in real terms. The private-economic analysis as conducted in the GEHHP-private scenario represents the optimal operation schedule and the costs from the end-consumer's point of view. The private-economic prices include energy taxes and are in nominal terms.

In this study, we model a simplified version of the GEHHP heating system as illustrated in figure 1 . We follow the system set-up introduced in the Freedom Project (2018), where a small heat pump (5kW capacity) is retrofitted to an existing gas boiler. According to the results of this project, this system set-up has proven to be functional and realistic. We assume that the lifetime of the combined GEHHP system equals the lifetime of the heat pump (15 years). Consi dering the lower gas boiler utilisation resulting from the presence of another heating source, and the age of the existing gas boiler, this assumption is possible. Thus, the onlyinvestment made in the hybrid system is the investment for the add-on heat pump. 
In the GEHHP model used in this article, the heat provided by the gas boiler and the heat pump fulfils the space heating demand by entering the heat circulation system directly, and heating water in a water storage tank up to 55 degrees Celsius. The only heating storage option in the simplified model is the water tank used for fulfilling the water heating demand. The objective of the model is the minimisation of operational costs resulting from gas and electricity consumption. The mathematical model is further explained in the section "supplementary information", together with the technical and economical framework conditions used for the calculations applied in this article

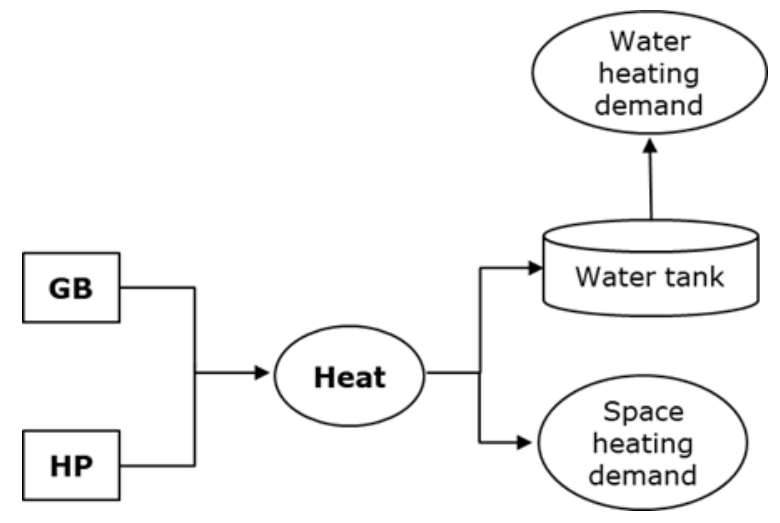

Figure 1: A simplified model of a GEHHP heating system

The power and gas consumption are the main variables the model adjusts to minimise the costs. According to the operation schedule of the GEHHP, the gas boiler and the heat pump cover the heat demand at all times. The amount of power and gas consumption depends on the efficiency of the gas boiler and heat pump and the cost of gas and power input. The parameter describing the efficiency of a heat pump is its Coefficient of Performance (COP). The value of this parameter depends on the individual heat pump characteristics and the ambient air temperature.

The COP values in this study should be interpreted with caution. In general the COP is lower for water heating than for space heating and the COP value of heat pumps varies strongly depending on the heat distribution system (Klein, Huchtemann and Müller, 2014). A thorough investigation of these matters would go beyond the scope of this study. However, a sensitivity analysis regarding the heat pump's COP is provided in the Supplementary Information section of this article.

Power and gas prices are important parameters in the GEHHP optimisation model. They are influencing the cost of heat provision from each of the GEHHP components. The combination of the power price with the COP of the heat pump, and the gas price with the gas boiler efficiency, are determining whether the GEHHP chooses the gas boiler or the heat pump for fulfilling the heat demand.

Figure 2 shows the socio- and private-economic power and gas price composition in the greater Copenhagen area. Grid operators usually calculate grid tariffs for end-users based on the consumption capacity and the customer sector. For the purpose of this study, we acknowledge that power and gas grids are operated as natural monopolies, where grid operators are not allowed to gain profit from 
operating the grid. The difference between the grid tariffs for different consumer sections, as commonly calculated by power and gas grid operators is neglected in this study. This enables us to conduct a clear analysis without these effects that vary depending on the specific grid operator, influencing our results. Therefore, the private-economic power and gas grid tariffs are identical to the socio-economic power- and gas grid tariffs.

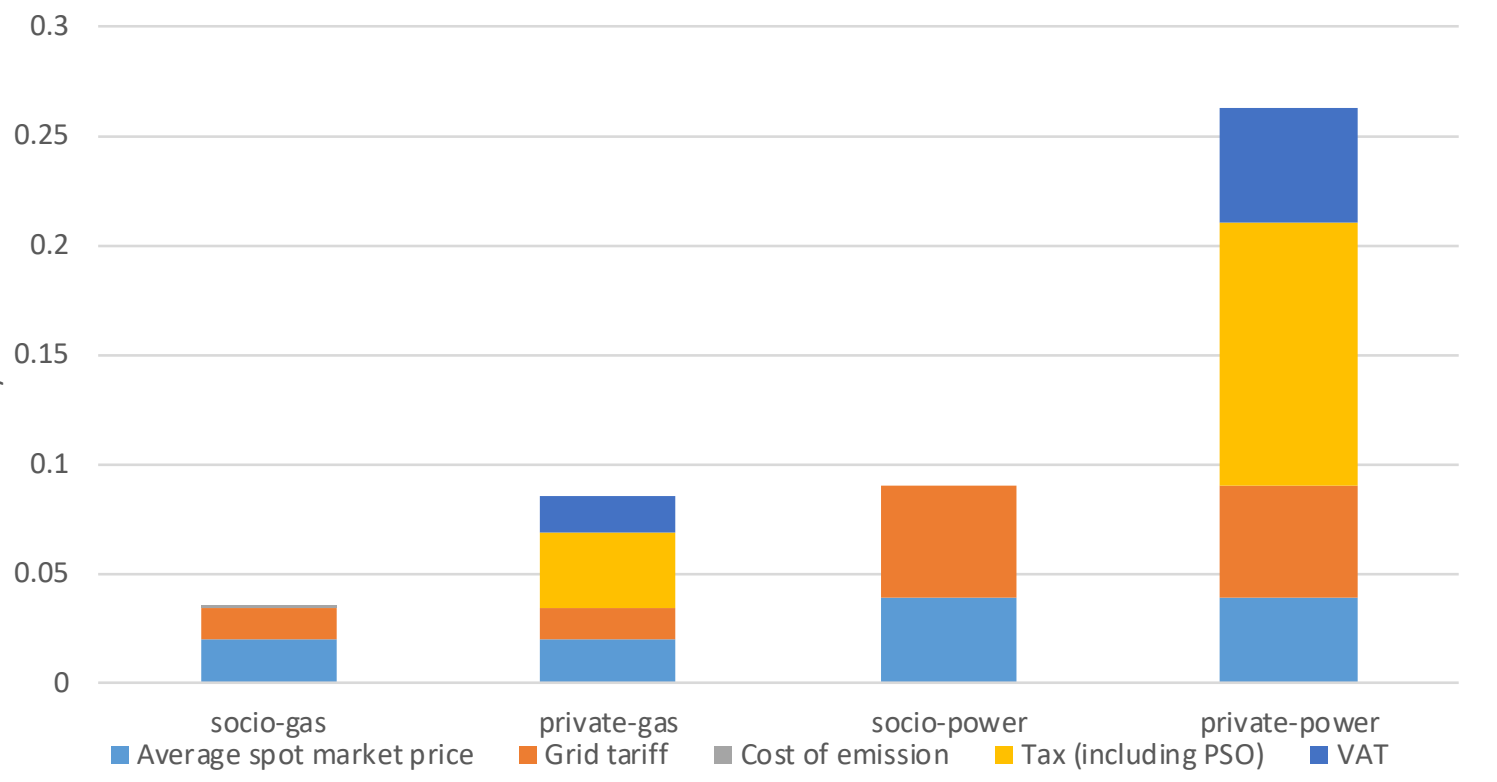

Figure 2: Socio- and private-economic power and gas price composition

In general, end consumers have to pay a higher power and gas price than the socio-economic price, because of the addition of taxes. The socio-economic model includes the cost of emission for society. We used the average $\mathrm{CO} 2$ prices from the EU Emission trading System as a benchmark for the cost of $\mathrm{CO} 2$ emission. The cost of other emission factors such as NOx, SOx, and particulate matter is neglected in this study, since it is very low and will not influence our results. The $\mathrm{CO} 2$ emissions from power production are already included in the spot market price, due to the integration of the European Emission Trading System (ETS) in the European power market.

\section{SCENARIOS FOR COST OPTIMISATION}

This section highlights the outcome of the cost optimisation model, and illustrates a number of scenarios. These scenarios focus on two aspects: the operation schedule of the GEHHP, and the comparison of the $\mathrm{LCOH}$ between the GEHHP and other technical alternatives. Table 1 presents these scenarios. The base-socio scenario, which is the reference point of this analysis, represents the GEHHP under the regulatory framework described in the previous section. The GEHHP -private scenario uses a model identical to the base-socio scenario, but with private economic prices including taxes, and a private-economic discount factor. The remaining scenarios are explained in this section. 


\begin{tabular}{|l|l|l|l|l|}
\hline Scenario name & Technology & Fuel & $\begin{array}{l}\text { Socio-or } \\
\text { Private- } \\
\text { economic }\end{array}$ & $\begin{array}{l}\text { Electricity grid } \\
\text { tariffs }\end{array}$ \\
\hline Base-socio & GEHHP & Natural gas + electricity & Socio & flat \\
\hline GEHHP-private & GEHHP & Natural gas + electricity & private & flat \\
\hline BM-socio & GEHHP & Natural gas + electricity & Socio & flat \\
\hline ToU-socio & GEHHP & Natural gas + electricity & Socio & ToU \\
\hline GB-socio & Gas boiler & Natural gas & Socio & flat \\
\hline GB-private & Gas boiler & Natural gas & Private & flat \\
\hline HP-socio & Heat pump & Electricity & Socio & flat \\
\hline HP-private & Heat pump & Electricity & Private & flat \\
\hline
\end{tabular}

\section{BM-socio scenario}

Part of the Danish energy agenda is to increase the share of biogas in the Danish gas grid (Danish Energy Agency, 2015). Danish biogas producers need to upgrade their biogas and inject it into the gas grid as biomethane. Therefore, we examine the GEHHPs using biomethane instead of natural gas in the BM-socio scenario. For this purpose, we add the increased cost of biomethane to the price of gas input in the GEHHP model. We reflect this increased cost using the product of the support paid to biogas plants and the net tax factor. Equation 1 shows the increased cost of the gas input in the BMsocio scenario. We assume that the state support given to biogas producers reflects the additional costs they have compared to natural gas producers. The support rate is currently at $0.055 € / \mathrm{kWh}$ (Danish Energy Agency, 2018a). The net tax factor is a factor reflecting the deadweight loss for the society resulting from the support provided to biomethane producers and is 1.325 (Danish Energy Agency, 2018b). We assume that this added cost is constant. However, in realitythe additional cost of biogas producers decreases over time due to technology diffusion and learning curve effects.

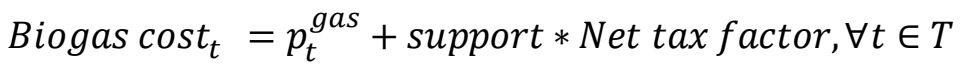

(Equation 1)

Biomethane in Denmark is mainly produced from manure. According to (Majer et al., 2016), manure based biomethane captures almost the same amount of carbon emissions as it is producing when it is incinerated. Therefore, the carbon emissions of biomethane are equal to zero.

\section{ToU-socio scenario}

In this scenario, we look at the implementation of Time of Use (ToU) electricity grid tariffs. These are tariffs that vary in their level based on the hours during which e lectricity is consumed (Saraiva et al., 2016). During peak-load hours the tariff is high, in order to discourage consumers from using electricity. The power distributor Radius A/S defines the hours 00-17 and 20-24 of every day as lowload hours and the hours 17-20 from October until March as peak-load hours. In order to study how strong the effect of ToU tariffs on the optimisation model is, we use the ToU tariffs currently 
implemented by Radius $\mathrm{A} / \mathrm{S}$, where tariffis $13.7 \%$ lower during low load, and $122 \%$ higher during peak load hours (Radius A/S, 2018).

GB-socio, GB private, HP-socio, and HP-private scenarios

These scenarios each represent an alternative heating technology to the GEHHP. The GB-socio and GB-private scenarios consider the use of a gas boiler as the only heating source for the household, while the HP-socio and HP-private scenarios consider the use of a heat pump. Since in the two latter scenarios the heat pump is supposed to fulfil the heat demand of the household, we use a heat pump with the capacity of $10 \mathrm{~kW}$ as suggested by (Danish Energy Agency and Energinet.dk, 2013).

\section{RESULTS}

\section{Operation Schedule}

As table 2 shows, in our base case, $12.8 \%$ of the heat demand is covered by the gas boiler component of the GEHHP, during its lifetime. The gas boiler component acts as a back up to the heat pump whereas the heat pump is the primary heat source of the household.

Table 2: Heating shares for all scenarios and heating alternatives

\begin{tabular}{|l|c|c|c|c|c|c|c|}
\hline \multicolumn{1}{|c|}{ Scenario } & Unit & Base-socio & $\begin{array}{c}\text { GEHHP- } \\
\text { private }\end{array}$ & BM-socio & ToU-socio & $\begin{array}{c}\text { GB only } \\
\text { scenarios }\end{array}$ & $\begin{array}{c}\text { HPonly } \\
\text { scenarios }\end{array}$ \\
\hline $\begin{array}{l}\text { Percentage of heat } \\
\text { provided by the gas } \\
\text { boiler }\end{array}$ & $\%$ & 12.8 & 24.7 & 0.1 & 14.1 & 100 & 0 \\
\hline $\begin{array}{l}\text { Percentage of heat } \\
\text { provided by the heat } \\
\text { pump }\end{array}$ & $\%$ & 87.2 & 75.3 & 99.9 & 85.9 & 0 & 100 \\
\hline
\end{tabular}

\section{Base-socio}

Running the model for the base scenario shows that in the base case, the gas boiler is only utilised during hours when the electricity price is very high, and temperatures are very low. Figure 3 shows the sum of heat provided by the heat pump and gas boiler component of the GEHHP, compared to the cost of heat provision by the respective component. This cost of heat consists of the power or gas price, divided by the efficiency of the heating source. It is visible in this figure, that the gas boiler provided heat to the household mainly during the winter months, especially January. 


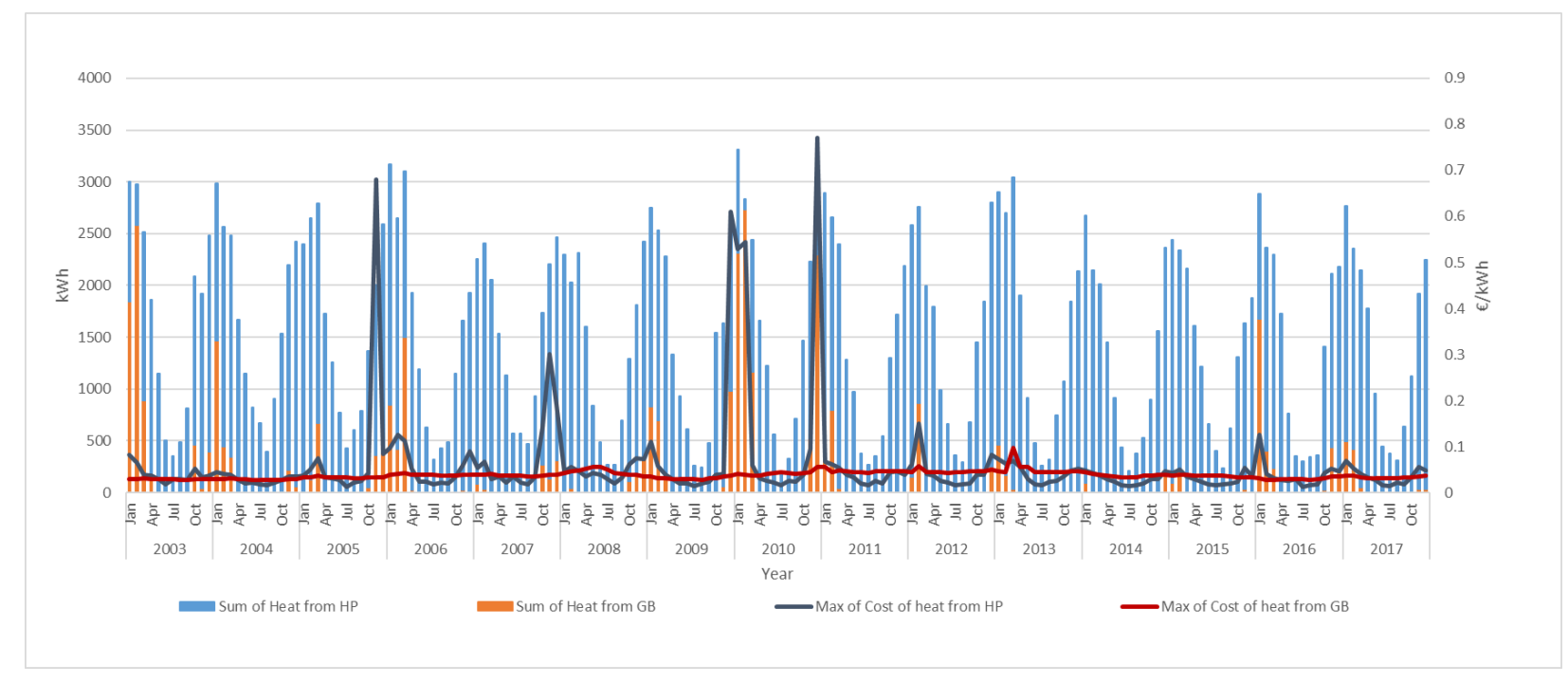

Figure 3: Operation schedule base scenario

\section{GEHHP-private scenario}

The private-economic analysis of the GEHHP system shows that a higher utilisation of the gas boiler would be optimal from the end-consumer's point of view. In this scenario, the gas boiler component provides around $24.7 \%$ of the household's heat during its lifetime. This is due to the fact that the sum of electricity taxes, including the PSO-tariff is higher than the energy taxes paid for natural gas consumption during more hours (see figure 2). This shows that taxes play an important role in the optimisation of the GEHHP's operation schedule.

\section{BM-socio scenario}

In the BM-socio, where biomethane is used as the input to the gas boiler component, the utilisation of the gas boiler is very low, and therefore neglectable. Only $0.1 \%$ of the heat within the 15 years lifetime of the GEHHP system is covered by the gas boiler. Thus, if the cost of biomethane remains at the state of 2018 , a hybrid system will not make sense.

\section{ToU-socio scenario}

Our results show that ToU tariffs influence the operation schedule of the GEHHP slightly. The utilisation of the gas boiler has increased by $1.3 \%$ in the ToU-socio scenario compared to the base case. This increase is happening during peak hours (between October and March). The reason for this insignificant increase is that the number of peak hours is relatively low in the Radius A/S ToU tariff scheme.

\section{Otherscenarios}

Since each of these scenarios consists of only one heating technology, the focus for the analysis of the GB-socio, GB private, HP-socio, and HP-private scenarios is the cost optimisation and how it stands compared to the base scenario. The results for these scenario analyses are presented in the following section. 


\section{Cost comparison}

The comparison of the $\mathrm{LCOH}$ of the different heating options, as listed in table 3 , shows that from a socio-economic point of view, the GEHHP offers the heating alternative with the lowest LCOH. The private-economic $\mathrm{LCOH}$ is on the same level for the heat pump only and the GEHHP system. The gas boiler only system proves to be the most expensive alternative. The influence of the energy costs for the gas boiler, exceed the influence of the lower investment costs for the gas boiler. The heat pump only system has the highest investment costs, since we assumed no new investment in the gas boiler component of the GEHHP system.

Table3: Cost comparison between GEHHPs and other individual heating alternatives

\begin{tabular}{|c|c|c|c|c|c|c|c|}
\hline & Unit & Base & $\begin{array}{c}\text { GEHHP- } \\
\text { private }\end{array}$ & GB-socio & GB-private & HP-socio & HP-private \\
\hline $\begin{array}{c}\text { Investment } \\
\text { cost* }\end{array}$ & $€ /$ unit & 4560.0 & 5912.7 & 3200.0 & 4084.0 & 5274.0 & 6730.9 \\
\hline $\begin{array}{c}\text { Operation and } \\
\text { Maintenance* } \\
*\end{array}$ & $€ /$ year & 268.0 & 340.3 & 235.0 & 297.9 & 188.0 & 238.7 \\
\hline $\begin{array}{c}\text { Energy cost } \\
\text { LCOH }\end{array}$ & $\begin{array}{c}€ / \text { lifetime** } \\
*\end{array}$ & 6078.1 & 17518.9 & 9896.2 & 24040.6 & 7028.9 & 20548.6 \\
\hline cent/kWh & 5.4 & 10.6 & 5.9 & 12.1 & 5.6 & 11.3 \\
\hline
\end{tabular}

*The costs for the private-economic scenarios include the annual inflation rate

**The Lifetime of the gas boiler is 20 years, and the lifetime of the heat pumps is 15 years. We subtracted the scrap value of the additional years of the gas boiler's lifetime from its costs.

\section{DISCUSSION}

Our results show, the GEHHP system utilises the gas boiler only during hours the electricity system is under pressure. This is in line with the initial thought behind the implementation of GEHHPs, which is that Hybrid heating systems offer flexibility to the electricity grid by enabling it to use electric heat pumps as a demand response variable. This can add value to the overall energy system, since it can reduce the need for investments in power grid expansion, which would be needed for the full electrification of the individual heating sector. This value is not included in this analysis, since we only look at the cost optimisation at the household level.

In the case of the instalment of a large number of electric heat pumps for individual heating, as part of retrofitting gas boilers to GEHHP systems, the power grid might require further expansion due to the increased aggregated power consumption. This can be a socio-economic cost factor, depending on what the base case of the analysis is. Region Hovedstaten (2018) argues that these costs need to be evaluated on a case-by-case basis, as the generalised consideration of capacity cannot necessarily be transferred to the specific conditions of a project. Additionally, aggregated GEHHPs have the possibility of participating in auxiliary service markets and thus the potential to obtain additional revenues.

For this study, we considered historical $\mathrm{CO} 2$ emission prices from 2007-2017. During the time-period of 2003-2007, there was no CO2 quota system in the European Union; hence, there were no CO2 costs associated with gas consumption and power production. Thus, we do not include the cost of emission for this time-period. This is not realistic in the context of today's ETS system, where CO2 prices have 
increased due to the renewal of the ETS system. This will increase the cost of the gas boiler only option and would decrease the hours of gas boiler utilisation in the GEHHP system.

Assuming that biomethane will replace natural gas in the gas grid over time, the analysis of GEHHPs using biomethane as an input for the gas boiler is highly relevant. The additional socio-economic green value will most likely change in the future, as we have used the support rate of 2018 and this rate is likely to decrease due to learning curve effects. There are a number of investment grants and support schemes, such as the Danish artisan payment deduction, that we have not considered in this study. The consideration of the se support schemes might change the operation schedule of a GEHHP using biomethane.

A household's heat demand is relatively inelastic (Hellmer, 2013). In light of ToU tariffs, which are initially a tool to incentivise lower power consumption during peak hours, a GEHHP enables the electricity demand for heating to respond to peak and off-peak prices, without compromising the fulfilment of the household's individual heat demand. Even though with the current number of peakload hours, the additional gas boiler utilisation might not be significant, in the case of increasing pe ak load hours and power price volatility in the future, this can add value to the energy system.

The way we dimensioned the heat pump in this study, does not reflect the real istic size of add -on heat pumps in hybrid heating systems. We chose a relatively large sized heat pump, in order to enable the system to exploit the arbitrage opportunities between the power and gas market.

The efficiency of the heat pump can have a strong influence on the optimisation results. This is demonstrated in the sensitivity analysis in the Supplementary Information section of this article. Thus, an analysis using a smaller heat pump, results in a higher utilisation of the gas boiler. This better reflects the current real-life GEHHP systems implemented in Denmark (Teknologisk Institut, 2015).

\section{CONCLUSION}

Our analysis shows that GEHHPs offer a cost-efficient individual heating solution, both from society's and the end-consumer's perspective. In GEHHP systems, the gas boiler provides heat during the hours where the electricity prices are peaking and the efficiency of the heat pump is low. Both in the socioand in the private-economic analysis the heat pump covers the main share of the heating demand for all scenarios. The gas boiler only system is the most expensive option from both a socio-, and privateeconomic perspective. This is due to the lower overall efficiency of the gas boiler, compared to highperforming air-to-water heat pumps.

Changing the input of the gas boiler from natural gas to biomethane causes the GEHHP system not to utilise the gas boiler component. This is due to the currently high cost of biomethane compared to natural gas. Thus, with the biomethane cost used in this study, a heat pump only system would be more sensible.

In this study, we investigated GEHHPs on a single household level. The effect of aggregated GEHHPs on local power and gas distribution networks is a subject that requires further examination. Additionally, we studied the most common set-up of GEHHP, which is the addition of a relatively small heat pump to an existing gas boiler. The results of our analysis, especially regarding the LCOH, would be different in case of investing into a new gas boiler component for the GEHHP. 
Additionally, an important point is that aggregated GEHHPs have the possibility of participating in auxiliary service markets and thus the potential to obtain additional revenues. Scholars should investigate this promising area further.

\section{ACKNOWLEDGMENTS}

We would like to thank Jean Schweizer and Karsten Frederiksen (DGC) for providing technical information on heat pumpsand gas boilers, and Niels TræholtFrank (Energinet), Alexander Kousgaard Sejbjerg (HMN Naturgas A/S), and Poul Erik Morthorst (Technical University of Denmark) for their support in data acquirement and constructive feedback. We are alsograteful to the reviewers for their valuable comments and feedback.

\section{FUNDING INFORMATION}

This paper is part of the Future Gas projects, funded by the Danish Council for Strategic Research (DSF), under the Strategic Research in Sustainable Energy and Environment" research programme (Grant number: 5160-00006B).

\section{REFERENCES}

Bagarella, G., Lazzarin, R. and Noro, M. (2016) 'Annual simulation, energy and economic analysis of hybrid heat pump systems for residential buildings', Applied Thermal Engineering. Elsevier Ltd, 99, pp. 485-494. doi: 10.1016/j.applthermaleng.2016.01.089.

Bergaentzlé, C. et al. (2019) 'Electricity grid tariffs as a tool for flexible energy systems: A Danish case study', Energy Policy, 126(November 2018), pp. 12-21. doi: 10.1016/j.enpol.2018.11.021.

Biegel, B. et al. (2013) 'Electricity market optimization of heat pump portfolio', pp. 294-301. doi: 10.1109/CCA.2013.6662774.

Brown, M. A., Zhou, S. and Ahmadi, M. (2018) 'Smart grid governance : An international review of evolving policy issues and innovations', Wiley Interdisciplinary Reviews: Energy and Environment, (January), pp. 1-26. doi: 10.1002/wene.290.

Bundesamt fuer Wirtschaft und Ausfuhrkontrolle (2019) Grenzübergangspreis bei Erdgas. Available at: https://www.bafa.de/DE/Energie/Rohstoffe/Erdgas/erdgas_node.html (Accessed: 22 August 2019).

Danish Energy Agency (2015) 'The Danish Energy Model', Danish Energy Agency. Available at: www.ens.dk/en.

Danish Energy Agency (2017) Samfundsøkonomiske Beregninsforudsætningerforenergipriserog emissioner. Kopenhagen.

Danish Energy Agency (2018a) Støtte til opgradering og rensning af biogas. Available at: https://ens.dk/ansvarsomraader/stoette-til-vedvarende-energi/biogas/stoette-til-opgradering-ogrensning-af-biogas (Accessed: 9 August 2018).

Danish Energy Agency (2018b) Vejledning i samfundsøkonomiske analyser på energiomradet. doi: 10.15713/ins.mmj.3.

Danish Energy Agency (2019a) Energistyrelsens Prisdatabase. 
Danish Energy Agency (2019b) 'Technology Data for Energy Plants for Electricity and District heating generation - Feb. 2019', (February).

Danish Energy Agency and Energinet.dk (2013) 'Technology data for energy plants - individual heating plants and energy transport', (August), p. 212. doi: ISBN: 978-87-7844-940-5.

Danish Energy Agency and Energinet (2016) 'Technology Data for Individual Heating Installations', (August 2016), p. 166. Available at:

https://ens.dk/sites/ens.dk/files/Analyser/technology_data_catalogue_for_heating_installations__marts_2018.pdf.

Danish Standards Association (2017) Varmepumpermed eldrevne apparater tilvarmt brugsvand af ydeevne og krav til mærkning af kompressorer-Prøvnitrg, beregning.

Danmarks Statistik (2018) Forbrugerprisindeks, gennemsnitlig årlig inflation (1900=100) efter type og tid. Availableat: http://www.statistikbanken.dk/statbank5a/selectvarval/saveselections.asp (Accessed: 15 June 2018).

Energinet.dk (2018) Hybridvarmepumper-Laerkevej-konvertering af naturgasopvarmning til varmepumperog hybridvarmepumper.

Energinet (2018) Energy Data Service. Available at: https://www.energidataservice.dk/ (Accessed: 18 September 2018).

Energistyrelsen (2007) Vejledning isamfundsøkonomiske analyser på energiområdet.

Fischer, D. and Madani, H. (2017) 'On heat pumps in smart grids: A review', Renewable and Sustainable Energy Reviews, 70(May 2016), pp. 342-357. doi: 10.1016/j.rser.2016.11.182.

Forsyningtilsynet (2019) Elprisstatistik. Available at:

http://forsyningstilsynet.dk/el/priser/elprisstatistik/ (Accessed:21 August 2019).

Frederiksen, C. (2014) 'Domestic gas hybrid technologies and their interaction with the Danish energy system', pp. 1-9.

Freedom Project (2018) 'Freedom Project - Final Report', (October). Available at:

https://www.wwutilities.co.uk/media/2829/freedom-project-final-report-october-2018. pdf.

Gaspoint Nordic A/S (2018) Gaspoint Nordic market data. Available at:

https://www.gaspointnordic.com/market-data (Accessed: 18September 2018).

Guminski, A. et al. (2018) 'System effects of high demand-side electrification rates: A scenario analysis for Germany in 2030', Wiley Interdisciplinary Reviews: Energy and Environment, (December 2017), p. e327. doi:10.1002/wene.327.

Hedegaard, K. and Münster, M. (2013) 'Influence of individual heat pumps on wind power integration - Energy system investments and operation', Energy Conversion and Management. Elsevier Ltd, 75, pp.673-684. doi:10.1016/j.enconman.2013.08.015.

Heinen, S., Burke, D. and O'Malley, M. (2016) 'Electricity, gas, heat integration via residential hybrid heating technologies - An investment model assessment', Energy. Elsevier Ltd, 109, pp. 906-919. doi:10.1016/j.energy.2016.04.126.

Hellmer, S. (2013) 'Price Responsiveness in District Heating: Single Houses and Residential Buildings-a Cross-Sectional Analysis', ISRN Economics, 2013, pp. 1-4. doi: 10.1155/2013/324127. 
Hohne, P. A., Kusakana, K. and Numbi, B. P. (2018) 'Operation cost and energy usage minimization of a hybrid solar/electrical water heating system', 2018 International Conference on the Domestic Use of Energy, DUE 2018. Cape Peninsula University of technology, pp. 1-7. doi:

10.23919/DUE.2018.8384387.

lowa State University (2018) Iowa EnvironmentalMesonet. Available at:

https://mesonet.agron.iastate.edu/request/download. phtml?network=DK_ASOS (Accessed: 23 May 2018).

Kelly, J. A., Fu, M. and Clinch, J. P. (2016) 'Residential home heating: The potential for air source heat pump technologies as an alternative to solid and liquid fuels', Energy Policy. Elsevier, 98, pp. 431442. doi: 10.1016/j.enpol.2016.09.016.

Klein, K., Huchtemann, K. and Müller, D. (2014) 'Numerical study on hybrid heat pump systems in existing buildings', Energy and Buildings. Elsevier B.V.,69, pp. 193-201. doi:

10.1016/j.enbuild.2013.10.032.

Li, F., Zheng, G. and Tian, Z. (2013) 'Optimal operation strategy of the hybrid heating system composed of centrifugal heat pumps and gas boilers', Energy and Buildings. Elsevier B.V., 58, pp. 2736. doi: 10.1016/j.enbuild.2012.09.044.

Lund, P. D. et al. (2015) 'Review of energy system flexibility measures to enable high levels of variable renewable electricity', Renewable and Sustainable Energy Reviews. Elsevier, 45, pp. 785807. doi: 10.1016/j.rser.2015.01.057.

Majer, S. et al. (2016) D5.3 Calculation of GHG emission caused by biomethane.

Meibom, P. et al. (2007) 'Value of electric heat boilers and heat pumps for wind power integration', Wind Energy, 10(4), pp. 321-337. doi: 10.1002/we.224.

Park, H. et al. (2014) 'Performance investigation of heat pump-gas fired water heater hybrid system and its economic feasibility study', Energy and Buildings. Elsevier B.V., 80, pp. 480-489. doi: 10.1016/j.enbuild.2014.05.052.

Di Perna, C. et al. (2015) 'Experimental assessment and dynamic analysis of a hybrid generator composed of an air source heat pump coupled with a condensing gas boiler in a residential building', Applied Thermal Engineering. Elsevier Ltd, 76, pp. 86-97. doi:

10.1016/j.applthermaleng.2014.10.007.

Pricerunner (2018) BOSCH Compress 7000i AW $13 \mathrm{~kW}$ luft/vand varmepumpe. Available at: https://www.pricerunner.dk/pl/693-3741517/Varmepumper/Bosch-Compress-7000i-AW-13-kWUdedel-Sammenlign-Priser (Accessed:10September 2018).

Radius A/S (2018) Tarifferog netabonnement. Available at:

http://www.radiuselnet.dk/elkunder/tariffer-afgifter-og-vilkår/tariffer-og-netabonnement (Accessed: 31 January 2018).

Region Hovedstaden (2018) Energipå tværs-Roadmap 2025-34 konkrete tiltag der sigter mod en fossilfrifremtid.

Ruokamo, E. (2016) 'Household preferences of hybrid home heating systems - A choice experiment application', Energy Policy. Elsevier, 95, pp. 224-237. doi: 10.1016/j.enpol.2016.04.017.

Saraiva, J. T. et al. (2016) 'Implementation of dynamic tariffs in the Portuguese electricity system Preliminary results of a Cost-Benefit Analysis', International Conference on the European Energy 
Market, EEM, 2016-July. doi: 10.1109/EEM.2016.7521329.

Schweitzer, J. et al. (2014) Domestic gas hybrid technologies and their interaction with the Danish energy system. Hørsholm.

Sneum, D. M. and Sandberg, E. (2018) 'Economicincentives for flexible district heating in the nordic countries', International Journal of Sustainable Energy Planning and Management, 16, pp. 27-44. doi: 10.5278/ijsepm.2018.16.3.

Söder, L. et al. (2018) 'A review of demand side flexibility potential in Northern Europe', Renewable and Sustainable Energy Reviews. Elsevier Ltd, 91(December 2016), pp. 654-664. doi: 10.1016/j.rser.2018.03.104.

Teknologisk Institut (2015) Feltmålinger på gashybridvarmepumper.

Tuohy, A., Kaun, B. and Entriken, R. (2014) 'Storage and demand-sideoptions for integrating wind power', Wiley Interdisciplinary Reviews: Energy and Environment, 3(1), pp. 93-109. doi:

10.1002/wene.92. 
